\title{
Prevalence of Brucella Antibodies in Migratory Fulani Cattle Herds in Kaduna State, Nigeria.
}

\author{
'MBUK, E. U., ${ }^{1}$ AJOGI, I., ${ }^{2}$ BALE, J.O.O. and ${ }^{1}$ UMOH, J.U.
}

${ }^{1}$ Dept. of Veterinary Public Health \& Preventive Medicine, ABU. ${ }^{2}$ National Animal Production Research Institute, ABU.

\section{Summary}

Brucellosis is a major cause of economic losses such as abortion, infertility, low conception rate and low survival rate of neonates in the livestock industry and zoonoses of great public health significance. The prevalence of Brucella antibodies in migratory Fulani cattle in Kaduna State was determined using the Milk Ring Test (MRT), Rose Bengal Plate Test (RBPT) and Microtitre Serum Agglutination Test (MSAT). This study determined the prevalence and the sources of transmission to local livestock populations and humans. A total of 2,799 serum and 2,149 milk samples from 93 Fulani cattle herds in 15 out of 23 Local Government Areas (LGAs) of the state were tested; in addition to application of structured questionnaire on the herdsmen. The prevalence rates obtained were $1.4 \%, 7.1 \%$ and $1.0 \%$ for MRT, RBPT and MSAT respectively. A control programme involving improved management, animal movement restrictions and public health education is suggested.

KEYWORDS: Prevalence, Brucella, antibodies, migratory cattle, Kaduna, Nigeria

\section{INTRODUCTION}

Brucellosis is a highly contagious zoonotic disease characterized by recurrent abortions and infertility in a variety of animal species and undulant fever in man (Halle and Ajogi, 1997).

Occupationally, Brucella can gain entry into humans (cattlemen, animal handlers, veterinarians, slaughterhouse workers) through unprotected breaks in the skin, mucous membranes, conjunctiva, respiratory and gastrointestinal tracts (Bale, 1991; Young, 1995; Corbel, 1997). There are about 18.4 million cattle in Nigeria (Ocholi et al., 2004a), out of which Kaduna State has 1.5 million. The White Fulani (Bos indicus) breed makes up about 90\% of this cattle population. Extensive husbandry system, where the pastoralists move around with their animals in search of green fields is widely practiced.

Brucellosis has been reported in various parts of Nigeria to have affected domestic animals (Ocholi et al., 2004a; Farouk, 2005) and humans (Baba et al., 1998). It is a major cause of economic losses in the livestock industry in terms of abortion, infertility, low conception rate and low survival rate of neonates (Enright, 1990; Halle and Ajogi, 1997; Ajogi and Akinwumi, 2001). Ocholi (1990) surveyed migratory cattle herds in Kaduna State and obtained Brucella antibody prevalence rate of $6.6 \%$. There is, need to update information on brucellosis in the state in order to create awareness and develop necessary intervention programmes.

\section{MATERIALS AND METHODS}

Blood and milk samples were collected from migratory cattle herds located in 15 randomly selected Local Government Areas of Kaduna State. The LGAs are; Birnin Gwari, Chikun, Kaduna North, Kachia, Lere, Kaduna South, Zango Kataf, Kaura, Jemma'a, Jaba, Giwa, Zaria, Soba, Kudan and Igabi.

Ten per cent of cattle were sampled in every herd in each of the 15 LGAs visited and animals with history of abortion, birth of weak calves, still births and infertility, and those showing signs of orchitis and hygroma were sampled. Questionnaires were administered to herd owners to assess their knowledge of human and bovine brucellosis. Other questions asked were: herd identity, herd composition, addition of replacement animals, milk yield and whether milk is pasteurized before consumption. All antigens used in this work were obtained from the Central Veterinary Laboratories Agency, NewHaw, Surrey, Weybridge, United Kingdom. Two thousand one hundred and forty-nine milk 
samples obtained from lactating cows in herds visited were screened for $B$. abortus antibodies using the Milk Ring Test (MRT) as described by Cruickshank et al. (1975). The serum samples were screened for $B$. abortus antibodies using the Rose Bengal Plate Test (RBPT) and confirmed by the Microtitre Serum Agglutination Test (MSAT) as described by Alton et al. (1988). Negative and positive controls were included in the MSAT and titres of 1:20 or 40 IU and above were considered positive for $B$. abortus antibodies.

The data obtained were analysed using the Chisquare test to check for association between age and sex and occurrence of antibody to Brucella organisms. The level of statistical significance was assessed at $\alpha=05$.

\section{RESULTS}

Questionnaire analysis showed that a total of 93 herds were visited in the 15 LGAs of Kaduna State. It was found that $70 \%$ of the herds visited moved to the southern part of the country during the dry season when feed stuff were depleted and return during the rainy season.

A total $35.5 \%$ of respondents claimed that they had at one time or the other vaccinated their animals against brucellosis. Abortion cases accounted for 8\% (176/2152). Stillbirths and birth of weak calves accounted for $2 \%$ $(35 / 2152)$ and 5\% (97/2152) respectively while, $3 \%(70 / 2457)$ of animals with hygroma were observed. There were reports of $1 \%$ prevalence of infertility in females and orchitis in males, but the herdsmen sold off unproductive animals. A total of $61.3 \%$ (57/93) of owners had knowledge of brucellosis and its modes of transmission while $36.6 \%$ (34/93) of owners said they boil milk before consumption.

Zango Kataf had the highest number of Brucella positive reactors $9(0.42 \%)$ following by, Jemma'a 5 (0.23\%), Birnin Gwari $4(0.18 \%)$, Chikun $4(0.18 \%)$, Kaduna North $3(0.14 \%)$, Kaduna south $2(0.09 \%)$, Kachia $1(0.05 \%)$, Lere 1 (0.05), while Jaba, Giwa, Zaria, Soba, Kudan and Igabi had $0.0 \%$.

The herd prevalence rate (HP) of brucellosis was $18.3 \%$ (17/93), while the individual animal prevalence rate (IAP) was $1.4 \%(31 / 2,149)$ from the 15 LGAs sampled.

The prevalence of Brucella antibodies in sampled cattle was highest in Zango Kataf for both RBPT and MSAT (1.11\% and $0.4 \%$ respectively), followed by Jemma'a (1.04\% and 0.07\%), Kaura $(0.68 \%$ and $0.07 \%)$, Jaba $(0.61 \%$ and $0.07 \%)$. The overall prevalence rates were $7.1 \%, 1.4 \%$ and $1.0 \%$ by RBPT, MRT and MSAT respectively, (Table I and II).

Table I: Evidence of Brucella antibodies in Kaduna State using Milk Ring Test (MRT)

\begin{tabular}{lll}
\hline $\begin{array}{l}\text { Source of milk } \\
\text { (LGA) }\end{array}$ & No. Examined & No. (\%) Positive \\
\hline Birnin Gwari & 156 & $4(0.18)$ \\
Chikun & 140 & $4(0.18)$ \\
Kaduna North & 113 & $3(0.14)$ \\
Kachia & 129 & $1(0.05)$ \\
Lere & 135 & $1(0.05)$ \\
Kaduna South & 126 & $2(0.09)$ \\
Zango Kataf & 150 & $9(0.42)$ \\
Kaura & 161 & $2(0.09)$ \\
Jemma'a & 151 & $5(0.23)$ \\
Jaba & 152 & $0(0.00)$ \\
Giwa & 151 & $0(0.00)$ \\
Zaria & 150 & $0(0.00)$ \\
Soba & 1.41 & $0(0.00)$ \\
Kudan & 150 & $0(0.00)$ \\
Igabi & 144 & $0(.00)$ \\
\hline Total & 2,149 & $31(1.40)$ \\
\hline
\end{tabular}

Table II: Prevalence of Bovine Brucellosis in Kaduna State as Detected by RBPT and MSAT

\begin{tabular}{llll}
\hline LGA & No. Sampled & $\begin{array}{l}\text { No.(\%)+ve } \\
\text { to RBPT }\end{array}$ & $\begin{array}{l}\text { No. }(\%)+v e \\
\text { to MSAT }\end{array}$ \\
\hline $\begin{array}{l}\text { Birinin Gwari } \\
\text { Chikun }\end{array}$ & 199 & $11(0.39)$ & $4(0.14)$ \\
Kaduna North & 178 & $6(0.21)$ & $2(0.07)$ \\
Kachia & 176 & $4(0.14)$ & $0(0.00)$ \\
Lere & 184 & $6(0.21)$ & $1(0.04)$ \\
Kaduna South & 158 & $3(0.11)$ & $1(0.04)$ \\
Zango Kataf & 205 & $8(0.29)$ & $2(0.07)$ \\
Kaura & 201 & $31(1.11)$ & $11(0.4)$ \\
Jemma'a & 201 & $19(0.68)$ & $2(0.07)$ \\
Jaba & 192 & $29(1.04)$ & $2((0.07)$ \\
Giwa & 193 & $17(0.61)$ & $2(0.07)$ \\
Zaria & 193 & $9(0.32)$ & $0(0.00)$ \\
Soba & 181 & $9(0.32)$ & $0(0.00)$ \\
Kudan & 188 & $16(0.57)$ & $0(0.00)$ \\
Igabi & 183 & $14(0.5)$ & $0(0.00)$ \\
\hline Total & 2,799 & $16(0.057)$ & $1(0.04)$ \\
\hline
\end{tabular}

Table III shows the variation in prevalence of bovine brucellosis by sex and age. Higher prevalence of $4.7 \%$ by RBPT and $0.8 \%$ by MSAT in both males and females of ages 2-3 years were observed in the 15 LGAs sampled. The differences in the infection rate between male and female were statistically significant 
$(\mathrm{p}<0.0001)$. The RBPT result shows that $3.89 \%$ $(109 / 1,159)$ of females of age 2-3years were positive compared to $0.82 \%(23 / 195)$ of males of same age. For animals above 3years old, $1.46 \%(41 / 488)$ of females tested positive compared to $0.11 \%(3 / 48)$ of males. $0.75 \%$ of the females of age 1-2years were positive while the males of same age group were negative. Females below 1year of age had only 1 (0.04) positive serum. Similarly, the MSAT result shows that $0.67 \%(19 / 1,159)$ females of age 2-3years tested positive compared to $0.14 \%(4 / 195)$ of males of the same age. While, $0.11 \%(3 / 488)$ of females above 3 years $0.04 \%$ of females of $1-2$ years and $0.04 \%$ of $<1$ year old females were positive at $40 \mathrm{IU}(1 / 20)$.

Table III: Distribution of Brucellosis in the Population of Cattle Sampled by Age and sex

\begin{tabular}{llll}
\hline Age and Sex & Total & $\begin{array}{l}\text { No. }(\%)+v e \\
\text { to RBPT }\end{array}$ & $\begin{array}{l}\text { No. }(\%)+v e \\
\text { to MSAT }\end{array}$ \\
\hline & FEMALE & & \\
<1year & 285 & $1(0.04)$ & $1(0.04)$ \\
1 -2years & 507 & $21(0.05)$ & $1(0.04)$ \\
2-3years & 1,159 & $109(3.89)$ & $19(0.67)$ \\
>3years & 488 & $41(1.46)$ & $3(0.11)$ \\
& MALE & & \\
<1year & 57 & $0(0.0)$ & $0(0.0)$ \\
1 -2years & 60 & $0(0.0)$ & $0(0.0)$ \\
2-3years & 195 & $23(0.82)$ & $4(0.14)$ \\
>3years & 48 & $3(0.11)$ & $0(0.0)$ \\
\hline Total & 2,799 & $198(7.1)$ & $28(1.0)$ \\
\hline
\end{tabular}

\section{DISCUSSION}

The detection of a higher prevalence of antibody titres by RBPT (7.1\%) than the MSAT (1.0\%) agrees with previous studies (Nicoletti, 1967; Morgan, 1967; Bale, 1980) and shows RBPT is more sensitive than MSAT. The MSAT result of $1.0 \%$ obtained in this presentation is less than the $6.6 \%$ reported by Ocholi (1990). This shows that, the prevalence of brucellosis may be on the decrease, probably because the farmers can recognize the symptoms, and have improved on the sanitary conditions of their farms with proper disposal of aborted materials. The prevalence rate of infection was highest among adult animals of age 2-3 years in both sexes. These animals are of breeding age, therefore the presence of brucellosis in the herds may result in reproductive wastages like abortion, neonatal mortality, infertility or sterility.

Females <1year of age had $0.04 \%$ infection. They may have been exposed through suckling of diseased cows or antibodies found may have been derived from maternal antibodies (Ocholi, 1990). These calves can shed Brucella organisms in their feces and contaminate the grazing grounds and could become diseased if they reach sexual maturity, thus serving as source of infection for other animals (Arthur et al., 1982). The prevalence of brucellosis was higher in the southern part (Zango Kataf, Jemma'a, Kaura and Jaba) of the state, which may be because of the congregation of animals in this area due to more greener pasture conducive for survival of Brucella in the environment compared to the drier Northern part (Ajogi, 1997). Many herds graze in proximity to and use the same water points thereby coming in contact with one another which could enhance the spread of the infection.

The MRT result of $1.4 \%$ found in this study is important because local customs encourage the consumption of raw bovine milk which predisposes to brucellosis (Ocholi et al., 2004b). With the developing dairy industry in Nigeria, human brucellosis should not be overlooked since the presence of brucellosis in animals is an indicator of its probable presence in man especially in those working with cattle or their by products or consuming unprocessed milk and milk products (Nuru and Dennis, 1975; Farouk 2005). A control programme involving improved management, animal movement restrictions and public health education is suggested.

\section{REFERENCES}

AJOGI, I. (1997): Seroprevalence of Brucellosis in slaughtered cattle in four Northern states of Nigeria. Tropical Veterinarian, 15:21-24.

AJOGI, I. AND AKINWUMI, J.A. (2001): Cash-flow model of the cost of brucellosis in traditionally managed cattle herds in Nigeria. Bulletin of Animal Health \& Production in Africa, 49:169-173.

ALTON, G.G., JONES, L.M., ANGUS, R.D. AND VERGER, J.M. (1988): Techniques for the brucellosis Laboratory. Institute National de al Recherche Agronomique. Paris, France, 63-129.

ARTHUR, G.H., NOAKES, D.F. AND PEARSON, H. (1982): Brucellosis. Veterinary Reproduction and Obstetrics. $5^{\text {th }}$ Edition. Bailliere Tindall, London, 742-745.

BABA, M.M., MOSES, A.E. AND AJAYI, B.B. (1998): Serological evidence of Brucella abortus infections 
in patients suspected of typhoid fever. Nigeria Medical practitioner, 35 (1/2): 9-11.

BALE, J.O.O. (1980): Cultural and Serological study of ovine and caprine brucellosis in Northern Nigeria. MSc Thesis. Ahmadu Bello Univeristy, Zaria, 1-20.

BALE, J.O.O. (1991): Brucellosis: A threat to livestock production and human health in Nigeria. A paper presented at a symposium at NAPRI, Shika, Zaria, 45.

CORBEL, M.J. (1997): Brucellosis: an overview. Emerging Infectious Diseases, 3:213-221.

CRUICKSHANK, A., DUGUID, J.P., MARMOIN, B.P. AND SWAIN, R.H.A. (1975): Brucellosis. Textbook of Medical Microbiology, $12^{\text {th }}$ edition, 1:290-390.

ENRIGHT, F.M. (1990): The Pathogenesis and pathobiology of Brucella infection in domestic animals. Animal brucellosis, 55:301-320.

FAROUK, U.M. (2005): Sero-prevalence of bovine brucellosis in cattle herds in Jigawa State, Nigeria. MSc Thesis. Ahmadu Bello University, Zaria, Nigeria, 12-28.

HALLE, P.D. AND AJOGI, I. (1997): Brucellosis in Nigeria: A review of recent developments. Israel journal of Veterinary Medicine, 52(4): 125-131.

MORGAN, W.J.B. (1967): The Serological diagnosis of bovine brucellosis. Veterinary record, 80:612.

NICOLETTI, P. (1967): Utilization of the card test in brucellosis eradication. Journal of American Veterinary Medical Association, 151:1778-1783.

NURU, S. AND DENNIS, S.M. (1975): Serological survey of brucellosis in slaughtered Cattle in North Central State of Nigeria. Journal of Nigerian Veterinary medical Association, 4:3-8.

OCHOLI, E.A. (1990): Prevalence of Brucella antibodies in Fulani cattle herds in Kaduna State. M.Sc. Thesis, Ahmadu Bello university, Zaria, 24-26.

OCHOLI, R.A., KWAGA, J.K.P., AJOGI, I. AND BALE, J.O.O. (2004a): Phenotypic characterization of Brucella strains isolated from livestock in Nigeria. Veterinary Microbiology, 103: 47-53.

OCHOLI, R. A., BERTU, W.J., KWAGA, J.K.P., AJOGI, I., BALE, J.O.O. AND OKPARA, J. (2004b): Carpal bursitis associated with Brucella abortus in a horse in Nigeria. The veterinary Record, 155:566-67.

YOUNG, E.J. (1995): An overview of human brucellosis. Clinical Infectious Diseases, 21:283-290. 